\title{
Recent advances in pathobiology and histopathological diagnosis of inflammatory bowel disease
}

\author{
Takuji Tanaka ${ }^{1,2,3^{*}}$ and Shigeyuki Sugie ${ }^{4}$ \\ *Correspondence: takutt@toukaisaibou.co.jp \\ 'Department of Tumor Pathology, Gifu University Grabudate School of Medicine, 1-1 Yanagido, Gifu City, Gifu 501-1194, Japan. \\ ${ }^{2}$ The Tohkai Cytopathology Institute: Cancer Research and Prevention (TCI-CaRP), 5-1-2 Minami-uzura, Gifu 500-8285, Japan. \\ ${ }^{3}$ Department of Pathology, Murakami Memorial Hospital, Asahi University, 3-23 Hashimoto-cho, Gifu 500-8523, Japan. \\ ${ }^{4}$ Department of Pathology, Murakami Memorial Hospital, Asahi University, 3-23 Hashimoto-cho, Gifu 500-8523, Japan.
}

\begin{abstract}
In order to make a diagnosis of ulcerative colitis (UC) or Crohn's disease (CD) which belongs to inflammatory bowel disease (IBD), it is important to evaluate pathologic material in conjunction with clinical, laboratory and endoscopic findings. There are several exceptions to the classical principles of IBD that may lead to diagnostic confusion. UC and CD have a variety of characteristic but also non-specific pathologic features. There are several exceptions to the classical principles of IBD that may lead to diagnostic confusion. This short review summarizes current diagnostic problems and advances with regard to histopathological findings of inflammation and dysplasia in biopsy specimens from UC and CD patients.

Keywords: IBD, ulcerative colitis, crohn's disease, pathobiology, histopathology, differential diagnosis
\end{abstract}

\section{Introduction}

Worldwide, the frequency of inflammatory bowel disease (IBD), including ulcerative colitis (UC) and Crohn's disease (CD) increased rapidly through the last century [1,2]. However, tends to be at the uppermost limit in developed countries [3]. On the other hand, the increase in the patients with IBD in the area where the frequency was low until now $[2,4]$, and the increase in the child cases of IBD are postulated [5-8]. Although the etiology of IBD is still unknown, it is supposed that immunological, hereditary, and environmental factors are involved by connecting with each other $[4,9,10]$. Several studies have suggested that a gene NOD2 contributes to development of $C D$ [11-13]. However, all the $C D$ patients do not have alterations of NOD2 [14], especially Japanese CD patients [15-17]. There is a differential genetic background of CD susceptibility between Japanese and European populations [18]. Recently, interesting findings showing an unexpected role of NOD2 in shaping a protective assembly of gut bacterial communities have been reported [19]. The findings also suggest that licensing of dysbiotic microbiota is a critical component of risk of CD.

\section{Histopathology of UC and CD}

$U C$ and $C D$ possess respectively their characteristic pathological findings. The pathological characteristics of UC include continued lesions from rectum that limit to the large bowel, and inflammation located in the mucosa. Histopathologically, chronic inflammation is uniform and accompanied with cryptitis (Figure 1) and crypt abscess (Figure 2), resulting in distinct cryptal distortion. In contrast, pathological lesions of $C D$ are found in small intestine, large bowel or both. CD could affect the whole alimentary tract. Thus, affected regions of CD are variable, when compared with UC. We should note the pathological findings of CD that are different from UC. Distribution of the lesions of CD is spots-like and continuous macroscopically and histopathologically. Inflammation of CD is found in all the intestinal tract layers. In addition, distortion of crypts in the mucosa is not prominent when compared with UC. Additionally, there are characteristic longitudinal ulcers in the intestinal tract of the patients with CD and histopathologically epithelioid cell granulomas (Figure 3). Gastric mucosal lesions are found with a high rate in CD patients. The lesions are focal inflammation containing granuloma(s) sometime and histologically called "focal enhanced gastritis". In early stages of $C D$, we often notice the aphthous lesions in the alimentary tract. We should differentiate the lesions that occur in $C D$ from infectious enteritis. Since histopathology of amebic colitis (Figure 4) resembles that of colonic CD and UC, and IBD can also be carriers of amebae [20-22], we must be careful of the presence of an amebae in the colonic mucosa of biopsies when diagnose IBD or not [23]. When diagnose such lesions in biopsy specimens, it is quite important to know the chronicity of inflammation. We should check the presence of infiltration of lymphocytes and plasma cells in the depth of mucosa (focal/ diffuse basal lymphoplasmacytosis), level branch and distortion of crypts, and mucosal atrophy.

\section{Cytomegalovirus (CMV) and amebae infection in IBD patients}

UC can present non-typical findings that are different from classic characteristics. They include mucosal inflammation nest (cecal 

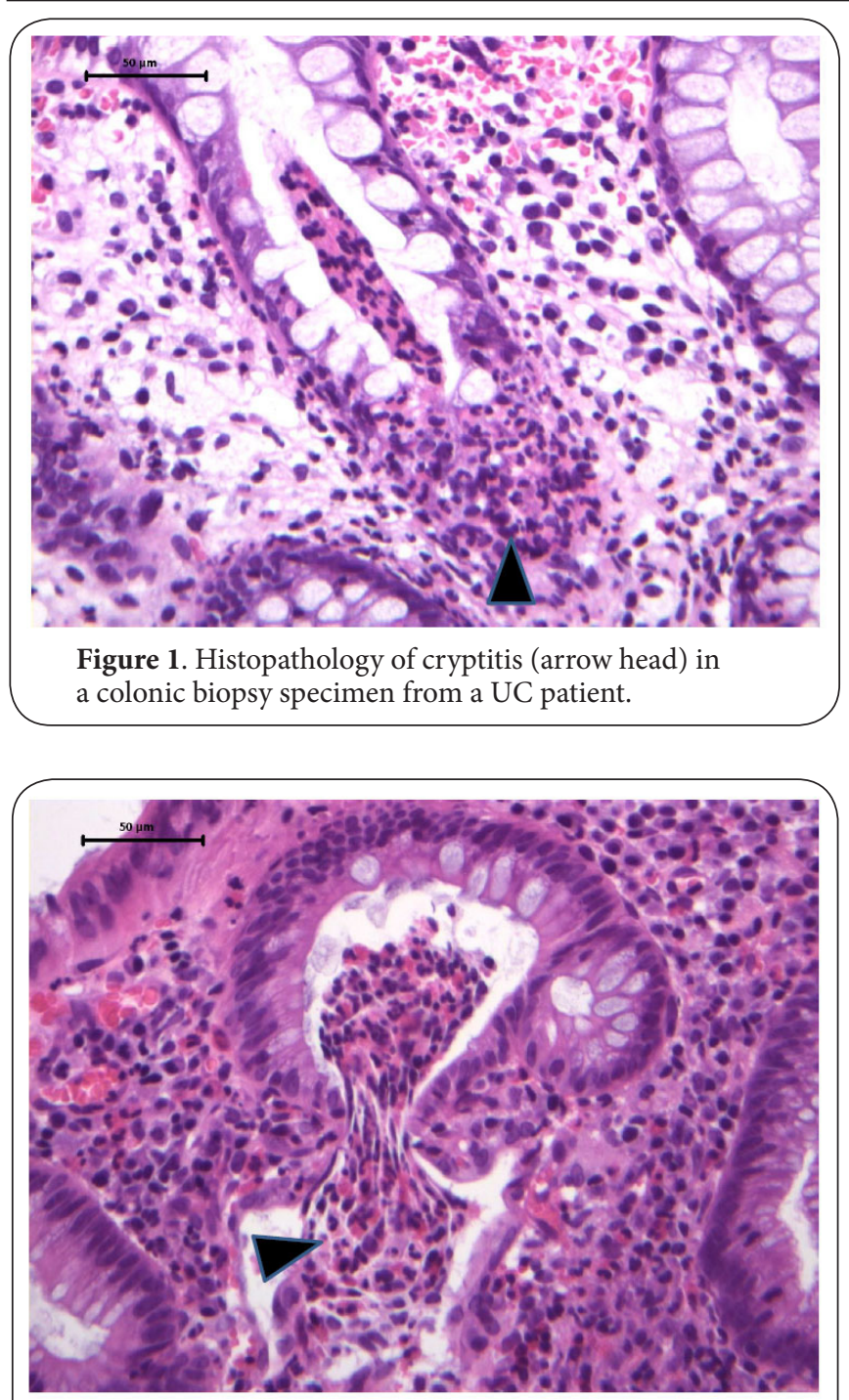

Figure 2. Histopathology of crypt abscess (arrow head) in a colonic biopsy specimen from a UC patient.

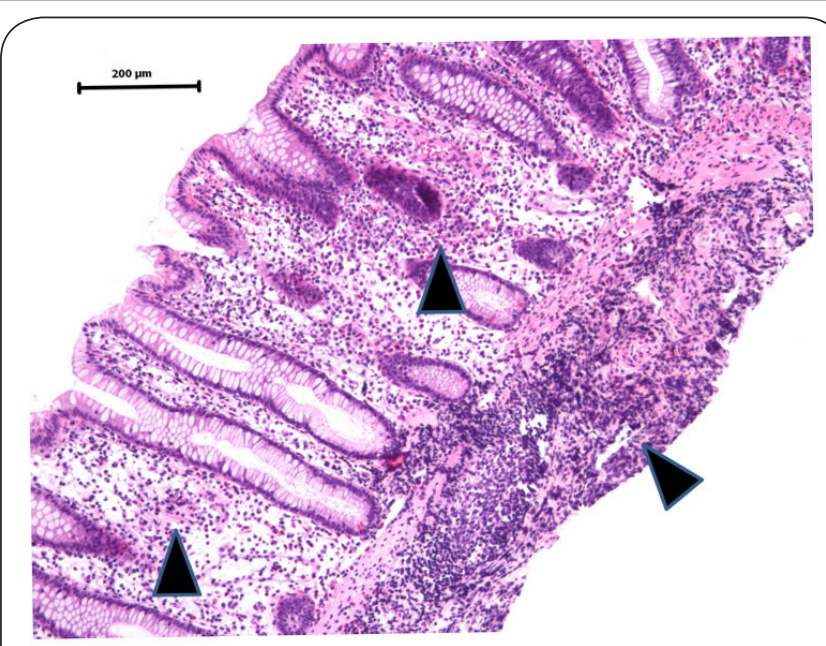

Figure 3. Histopathology of granulomas (arrow heads) in a colonic biopsy specimen from a CD patient.

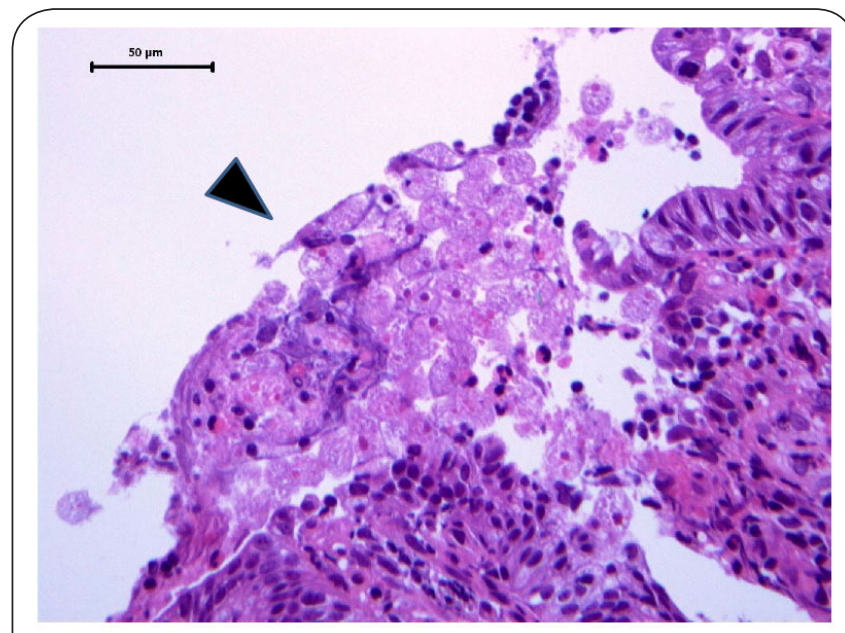

Figure 4. Many Entamoeba histolytica (arrow head) are present in a colonic biopsy specimen from a patient with amebic colitis. patch) in the right colon, cecum in particular, appendices aperture circumference mucosa that is a discontinuous lesion of that of left colon and lack or slight of spot inflammation in the rectal mucosa (rectal sparing). It should be keep in mind that discontinuous distribution of spots-like lesions, and endoscopic or histological rectal sparing are detected in the cases of UC patients receiving long-term treatment. Moreover, it is possible to find CMV (Figure 5) infection when inflammation recurred in UC patients that obtain remission for a long-term [24-27]. Therefore, it is necessary not to overlook CMV-infected large cells and inclusion bodies on the occasion of biopsy tissue diagnosis.

Recently, de novo IBD that develops after solid organ transplantation and is a more common UC than CD is recognized $[\mathbf{2 8 , 2 9 ]}$. The incidence of de novo IBD in the transplanted patients is ten-times higher than the expected incidence of IBD in the general population [28]. The major risk factor of de novo IBD is considered to be CMV infection $[30,31]$. Significance of CMV infection is also reported in a murine colitis model [32].

\section{Indeterminate colitis}

By a part of IBD, there are cases called "indeterminate colitis" $[33,34]$ when diagnosis of UC or CD is difficult. Most cases of "indeterminate colitis" are related to fulminant colitis, a condition in which the classical features of UC or CD may be obscured by severe ulceration with early superficial fissuring ulceration, transmural lymphoid aggregates, and relative rectal sparing. Approximately $20 \%$ of patients with "indeterminate colitis" develop severe pouch complications that occur in $8-10 \%$ of UC and $30-40 \%$ CD [35]. Although the name "indeterminate colitis" was used for the findings in the 


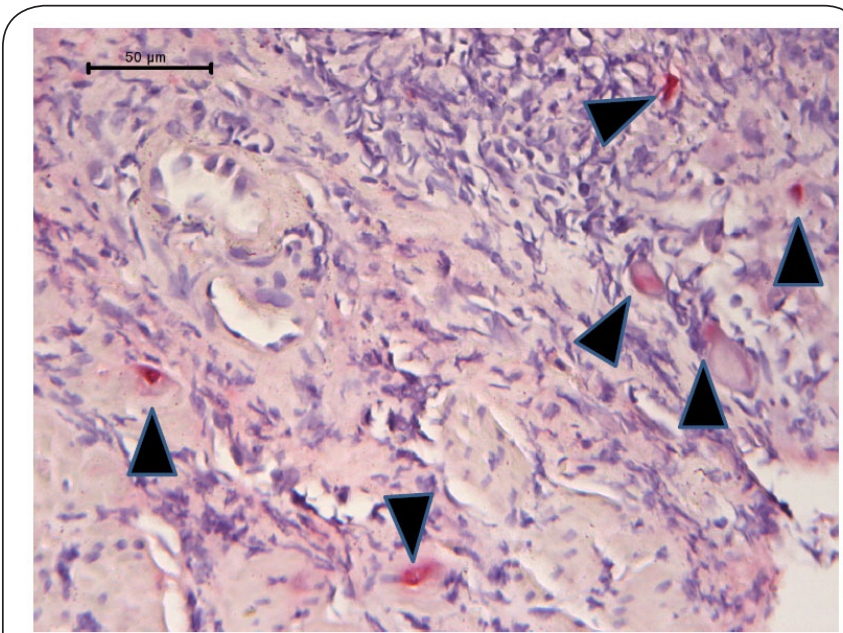

Figure 5. Cytomegalovirus (CMV, arrow heads) detected by immunohistochemistry using a monoclonal antibody against CMV in a colonic biopsy specimen from a UC patient.

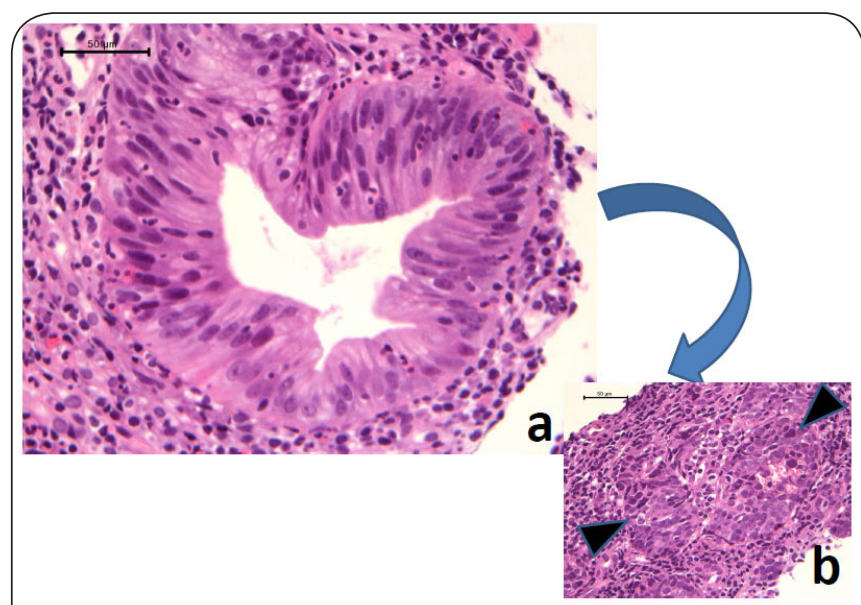

Figure 6. Dyspastic crypt (a) found surrounding adenocarcinoma glands (b, arrow heads) in a colon from a UC patient.

intestine surgically excited, it is also used for the findings when it is difficult to diagnose UC or CD by endoscopical and pathological biopsy examinations using biopsy specimens. Follow-up observation of these cases enables us to make diagnosis of UC or CD in most cases, when early lesions, differentiation from infectious enteritis, non-typical findings of IBD, therapeutic influence, and re-biopsy are considered.

Additionally, biopsy specimens that are taken from areas of severely inflamed polypoid mucosa, such as cap polypsos, histopathologically mimick colitis in IBD [36,37]. Intestinal Behçet's disease is a subtype of the disease causing abdominal pain, diarrhea, and melena [38]. The ileocecal region is the most frequently affected, although lesions can be distributed in any parts of the gastrointestinal tract. Rounded or oval punched-out type ulcerations like simple ulcers are the most characteristic pathological feature, while non-specific diffuse ulcerations and granulomatous lesions are similar to $C D$ and UC. Thus, it is sometimes difficult to differentiate IBD from intestinal Behçet's disease based on extraintestinal symptoms as well as intestinal lesions [37]. One interesting case, in which a patient who was diagnosed with Behçet's disease after the diagnosis of UC have been established for more than 15 years [39] was reported. It is likely that a similar pathogenesis mediates the development of Behçet's disease and IBD, especially UC.

\section{Colorectal cancer (CRC) in IBD patients}

It is known that the risk of CRC development significantly increases in the patients of IBD $[1,40]$. Patients with UC and $\mathrm{CD}$ bear an about 10- and 4-fold increased risk, respectively, for developing CRC $[1,41]$. The risk increases more in the cases with long disease years [1], those with affected area, those with pan-colitis that developed during childhood. The risk for neoplasm also depends on therapeutic responsiveness of chronic inflammation and seems pathogenetically to be similar in UC and CD. In many cases in which altered crypts relevant to IBD, dysplastic crypts (Figure 6a) other than CRC (Figure $6 \mathrm{~b}$ ) are frequently found and thus it is considered that CRC in IBD arises from this cryptal dysplasia. Dysplasia does not form clear pathological lesions (called flat dysplasia) and therefore it is difficult to detect it by endoscopic examination. Many random biopsies is required for the surveillance and several guidelines are proposed.

There is protruded lesion other than flat dysplasia in dysplasia developed in the large bowel of IBD. These lesions are called "dysplasia-associated lesion or mass (DALM)" [35,42-44] and often coexist with CRC. It has been considered that in such cases intestinal tract should be excised. However, some protruded dysplastic lesions resemble conventional adenoma and can be excised by endoscope. The lesions are called polypoid IBD-associated dysplasia (polypoid dysplasia) [45-49]. Polypoid dysplasia should be distinguished from the conventional adenomas. Many cases of polypoid dysplasia develop in younger patients rather than the patients with the conventional adenomas and have active inflammation and a long disease period. Histopathologically, polypoid dysplasia shows severe inflammatory cell infiltration and dysplastic crypts and non-dysplastic crypts are intermingled in the colorectum.

Recently, programmed cell death 4 (PDCD4) has been demonstrated to be a new tumor suppressor gene in several tissues [50-52], including colorectum [53]. Although normal colonocytes and hyperplastic polyp show strong PDCD4 nuclear immunostaining, a significantly lower PDCD4 nuclear expression is observed in tubular/serrated adenomas and invasive CRC [54]. PDCD4 immunostaining and mRNA levels decreased significantly as the phenotypic changes occurring during colon carcinogenesis progressively increased. In 


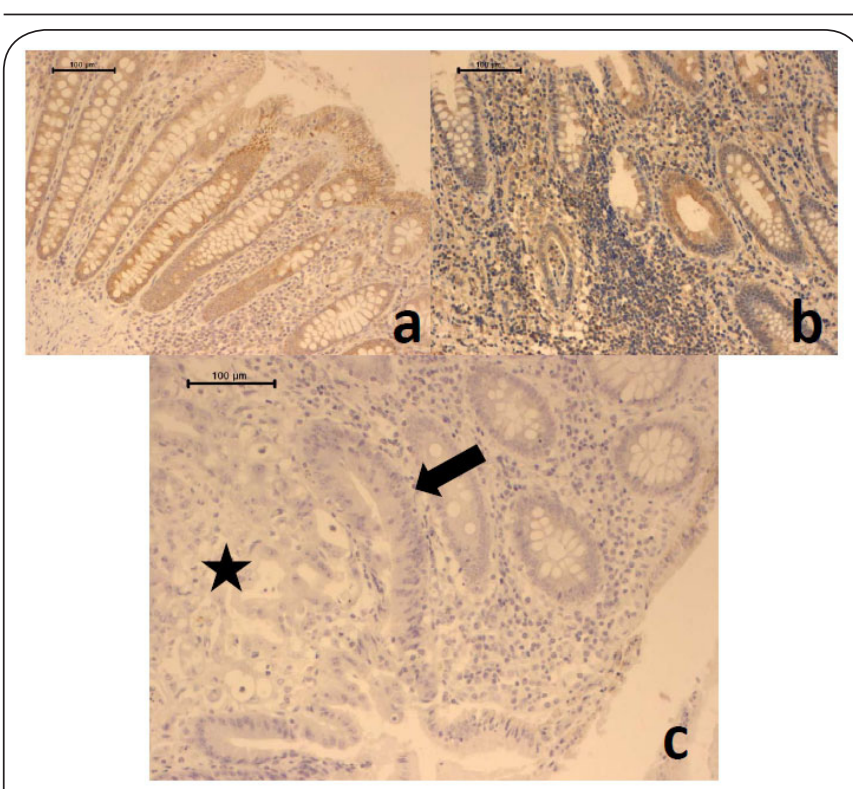

Figure 7. PDCD4 immunohistochemistry of the colon from Japanese UC patients with CRC. (a) Positive immunostain in the cytoplasm and nucleus of crypts in inactive UC; (b) Weakly positive reaction in the cytoplasm and nucleus of crypts in active UC; and (c) Negative immunostain in dysplastic crypt (arrow), adenocarcinoma cells (star), and surrounding crypts. PDCD4 immunohistochemistry using a primary antibody (anti-PCDC4 rabbit polyclonal antibody, Atlas Antibodies AB, Stockholm, Sweden, Cat. No. HPA001032) with dilution rate 1:500, Bars, $100 \mu \mathrm{m}$.

addition, expression of a major PDCD4 regulator, miR-21, is significantly upregulated in preneoplastic and neoplastic lesions, consistent with PDCD4 downregulation [54]. As found in sporadic colorectal oncogenesis, non-lesional colonocytes and inactive IBD show strong PDCD4-nuclear immunostain, but lower PDCD4 nuclear expression is found in both active IBD (Figure 7) and IBD-associated dysplastic lesions (Figure 7) [55]. We recently confirmed these immunohistochemical findings of PDCD4 in Japanese UC patients with CRC (Figure 7). PDCD4 down-regulation in both active IBD and dysplasia is significantly associated with miR-21 up-regulation [55]. The findings indicate that PDCD4 nuclear down-regulation, which parallels miR-21 up-regulation is involved in the molecular pathway of IBD-associated colorectal carcinogenesis. Thus, PDCD4 nuclear expression could be a novel maker in the histological assessment of IBD-associated dysplastic lesions. Additionally, PDCD4 has a potential value as a molecular target in cancer therapy $[\mathbf{5 1 , 5 2 , 5 6 ]}$, although recent data suggest that PDCD4 function may depend on cell type and/ or genetic background [52].

\section{Conclusion}

As mentioned above, pathologists play the important role in the diagnosis of IBD, especially in differential diagnosis of UC and $C D$, determination of the grade of inflammation, presence or absence of complications, including dysplasia and CRC.

\section{List of abbreviations}

IBD: Inflammatory bowel disease

UC: Ulcerative colitis

CD: Crohn's disease

CMV: Cytomegalovirus

CRC: Colorectal Cancer

DALM: Dysplasia-associated lesion or mass

PDCD4: Programmed cell death 4

Competing interests

The authors declare that they have no competing interests.

\section{Authors' contributions}

All authors participated in the conception and design of the study. TT and SS summarized the extracted data. TT wrote the manuscript with contributions from SS. All authors read and approved the final manuscript.

\section{Acknowledgement and funding}

Funding was provided from the Ministry of Health and Welfare (a Grant-in-Aid for the 2nd and 3rd Terms Comprehensive 10-Year Strategy for Cancer Control) and the Ministry of Education, Science, Sports and Culture (Grants-in-Aid, nos. 13671986 and no. 23501324) of Japan.

\section{Publication history}

Received: 09-May-2013 Revised: 13-May-2013

Accepted: 14-May-2013 Published: 15-May-2013

\section{References}

1. Tanaka T: Colorectal carcinogenesis: Review of human and experimental animal studies. J Carcinog 2009, 8:5. | Article | PubMed Abstract | PubMed Full Text

2. Burisch J, Jess T, Martinato M and Lakatos PL: The burden of inflammatory bowel disease in Europe. J Crohns Colitis 2013, 7:322-37. | Article I PubMed

3. Ng SC, Bernstein CN, Vatn MH, Lakatos PL, Loftus EV, Jr., Tysk C, O'Morain C, Moum B and Colombel JF: Geographical variability and environmental risk factors in inflammatory bowel disease. Gut 2013, 62:630-49. | Article I PubMed

4. Frolkis A, Dieleman LA, Barkema H, Panaccione R, Ghosh S, Fedorak RN, Madsen $\mathrm{K}$ and Kaplan GG: Environment and the inflammatory bowel diseases. Can J Gastroenterol 2013, 27:e18-24. I Article I PubMed

5. Bousvaros A, Morley-Fletcher A, Pensabene L and Cucchiara S: Research and clinical challenges in paediatric inflammatory bowel disease. Dig Liver Dis 2008, 40:32-8. I Article I PubMed

6. Griffiths AM: Specificities of inflammatory bowel disease in childhood Best Pract Res Clin Gastroenterol 2004, 18:509-23. I Article I PubMed

7. Malmborg P, Grahnquist L, Lindholm J, Montgomery S and Hildebrand $\mathrm{H}$ : Increasing Incidence of Paediatric Inflammatory Bowel Disease in Northern Stockholm County 2002-2007. J Pediatr Gastroenterol Nutr 2013. | Article | PubMed

8. Taminiau JA: Review article: The clinical importance of growth in children with inflammatory bowel disease: is it important to the gastroenterologist? Aliment Pharmacol Ther 2007, 26 Suppl 2:53-6. | Article | PubMed

9. Gerasimidis K, McGrogan P and Edwards CA: The aetiology and impact of malnutrition in paediatric inflammatory bowel disease. $J$ Hum Nutr Diet 2011, 24:313-26. | Article | PubMed

10. Leone V, Chang EB and Devkota S: Diet, microbes, and host genetics: the perfect storm in inflammatory bowel diseases. J Gastroenterol 2013, 48:315-21. I Article I PubMed

11. Hugot JP, Chamaillard M, Zouali H, Lesage S, Cezard JP, Belaiche J, Almer S, Tysk C, O'Morain CA, Gassull M, Binder V, Finkel Y, Cortot A, Modigliani R, Laurent-Puig P, Gower-Rousseau C, Macry J, Colombel JF, Sahbatou M and Thomas G: Association of NOD2 leucine-rich repeat variants with susceptibility to Crohn's disease. Nature 2001, 411:599-603. | Article | 
Tanaka et al. Pathology Discovery 2013,

http://www.hoajonline.com/journals/pdf/2052-7896-1-1.pdf

doi: $10.7243 / 2052-7896-1-1$

\section{PubMed}

12. Ogura $\mathrm{Y}$, Bonen DK, Inohara N, Nicolae DL, Chen FF, Ramos R, Britton H, Moran T, Karaliuskas R, Duerr RH, Achkar JP, Brant SR, Bayless TM, Kirschner BS, Hanauer SB, Nunez G and Cho JH: A frameshift mutation in NOD2 associated with susceptibility to Crohn's disease. Nature 2001, 411:603-6. | Article | PubMed

13. Strober W, Fuss I and Mannon P: The fundamental basis of inflammatory bowel disease. J Clin Invest 2007, 117:514-21. | Article | PubMed Abstract | PubMed Full Text

14. Negoro K, McGovern DP, Kinouchi Y, Takahashi S, Lench NJ, Shimosegawa T, Carey A, Cardon LR, Jewell DP and van Heel DA: Analysis of the IBD5 locus and potential gene-gene interactions in Crohn's disease. Gut 2003, 52:541-6. | Article | PubMed Abstract | PubMed Full Text

15. Inoue N, Tamura K, Kinouchi Y, Fukuda Y, Takahashi S, Ogura Y, Inohara N, Nunez G, Kishi Y, Koike Y, Shimosegawa T, Shimoyama T and Hibi T: Lack of common NOD2 variants in Japanese patients with Crohn's disease. Gastroenterology 2002, 123:86-91. | Article | PubMed

16. Yamazaki K, Takazoe M, Tanaka T, Kazumori T and Nakamura Y: Absence of mutation in the NOD2/CARD15 gene among 483 Japanese patients with Crohn's disease. J Hum Genet 2002, 47:469-72. I Article I PubMed

17. Tosa M, Negoro K, Kinouchi Y, Abe H, Nomura E, Takagi S, Aihara H, Oomori S, Sugimura M, Takahashi K, Hiwatashi N, Takahashi S and Shimosegawa T: Lack of association between IBD5 and Crohn's disease in Japanese patients demonstrates population-specific differences in inflammatory bowel disease. Scand J Gastroenterol 2006, 41:48-53. I Article I PubMed

18. Hirano A, Yamazaki K, Umeno J, Ashikawa K, Aoki M, Matsumoto T, Nakamura S, Ninomiya T, Matsui T, Hirai F, Kawaguchi T, Takazoe M, Tanaka H, Motoya S, Kiyohara Y, Kitazono T, Nakamura Y, Kamatani $\mathrm{N}$ and Kubo M: Association study of 71 European Crohn's disease susceptibility loci in a Japanese population. Inflamm Bowel Dis 2013, 19:526-33. | Article | PubMed

19. Couturier-Maillard A, Secher T, Rehman A, Normand S, De Arcangelis A, Haesler R, Huot L, Grandjean T, Bressenot A, Delanoye-Crespin A, Gaillot $O$, Schreiber S, Lemoine Y, Ryffel B, Hot D, Nunez G, Chen G, Rosenstiel $P$ and Chamaillard M: NOD2-mediated dysbiosis predisposes mice to transmissible colitis and colorectal cancer. J Clin Invest 2013, 123:70011. | Article | PubMed Abstract | PubMed Full Text

20. Korelitz BI: When should we look for amebae in patients with inflammatory bowel disease? J Clin Gastroenterol 1989, 11:373-5. | Article | PubMed

21. Malatjalian DA: Pathology of inflammatory bowel disease in colorectal mucosal biopsies. Dig Dis Sci 1987, 32:5S-15S. I Article | PubMed

22. Patel AS and DeRidder PH: Amebic colitis masquerading as acute inflammatory bowel disease: the role of serology in its diagnosis. $J$ Clin Gastroenterol 1989, 11:407-10. | Article | PubMed

23. Yardley $\mathrm{JH}$ and Donowitz $\mathrm{M}$ : Colo-rectal biopsy in inflammatory bowel disease. Monogr Pathol 1977, 50-94. I PubMed

24. Berk T, Gordon SJ, Choi HY and Cooper HS: Cytomegalovirus infection of the colon: a possible role in exacerbations of inflammatory bowel disease. Am J Gastroenterol 1985, 80:355-60. | Article | PubMed

25. Chiba M, Abe T, Tsuda S and Ono I: Cytomegalovirus infection associated with onset of ulcerative colitis. BMC Res Notes 2013, 6:40. | Article | PubMed Abstract | PubMed Full Text

26. Domenech E, Vega R, Ojanguren I, Hernandez A, Garcia-Planella E, Bernal I, Rosinach M, Boix J, Cabre E and Gassull MA: Cytomegalovirus infection in ulcerative colitis: a prospective, comparative study on prevalence and diagnostic strategy. Inflamm Bowel Dis 2008, 14:1373-9. | Article | PubMed

27. Matsuoka K, Iwao Y, Mori T, Sakuraba A, Yajima T, Hisamatsu T, Okamoto S, Morohoshi Y, Izumiya M, Ichikawa H, Sato T, Inoue N, Ogata H and Hibi $\mathrm{T}$ : Cytomegalovirus is frequently reactivated and disappears without antiviral agents in ulcerative colitis patients. Am J Gastroenterol 2007, 102:331-7. | Article I PubMed

28. Hampton DD, Poleski MH and Onken JE: Inflammatory bowel disease following solid organ transplantation. Clin Immunol 2008, 128:287-93. I Article I PubMed
29. Sun L, Nava GM and Stappenbeck TS: Host genetic susceptibility, dysbiosis, and viral triggers in inflammatory bowel disease. Curr Opin Gastroenterol 2011, 27:321-7. | Article | PubMed

30. Verdonk RC, Dijkstra G, Haagsma EB, Shostrom VK, Van den Berg AP, Kleibeuker JH, Langnas AN and Sudan DL: Inflammatory bowel disease after liver transplantation: risk factors for recurrence and de novo disease. Am J Transplant 2006, 6:1422-9. | Article | PubMed

31. Verdonk RC, Haagsma EB, Van Den Berg AP, Karrenbeld A, Slooff MJ, Kleibeuker JH and Dijkstra G: Inflammatory bowel disease after liver transplantation: a role for cytomegalovirus infection. Scand J Gastroenterol 2006, 41:205-11. | Article | PubMed

32. Onyeagocha C, Hossain MS, Kumar A, Jones RM, Roback J and Gewirtz AT: Latent cytomegalovirus infection exacerbates experimental colitis. Am J Pathol 2009, 175:2034-42. | Article | PubMed Abstract | PubMed Full Text

33. Guindi M and Riddell RH: Indeterminate colitis. J Clin Pathol 2004, 57:1233-44. | Article | PubMed Abstract | PubMed Full Text

34. Mitchell PJ, Rabau MY and Haboubi NY: Indeterminate colitis. Tech Coloproctol 2007, 11:91-6. | Article | PubMed

35. Odze R: Diagnostic problems and advances in inflammatory bowel disease. Mod Pathol 2003, 16:347-58. I Article | PubMed

36. Kini GP, Murray I, Champion-Young J, Lau M, Katta V, Thorn M and Schultz MP: Cap polyposis mistaken for Crohn's disease: case report and review of literature. J Crohns Colitis 2013, 7:e108-11. | Article | PubMed

37. Kara T and Dusmez Apa D: Pathologic Features of Behcet's Disease in the Tubuler Gut. Patholog Res Int 2012, 2012:216254. | Article | PubMed Abstract | PubMed Full Text

38. Naganuma $\mathrm{M}$, Iwao $\mathrm{Y}$, Inoue $\mathrm{N}$, Hisamatsu $T$, Imaeda $\mathrm{H}$, Ishii $\mathrm{H}$, Kanai $\mathrm{T}$, Watanabe $M$ and Hibi T: Analysis of clinical course and long-term prognosis of surgical and nonsurgical patients with intestinal Behcet's disease. Am J Gastroenterol 2000, 95:2848-51. | Article | PubMed

39. Kobashigawa T, Okamoto $\mathrm{H}$, Kato J, Shindo H, Imamura T, lizuka $\mathrm{BE}$, Tanaka M, Uesato M, Ohta SJ, Terai C, Hara M and Kamatani N: Ulcerative colitis followed by the development of Behcet's disease. Intern Med 2004, 43:243-7. | Article | PubMed

40. Yano Y, Matsui T, Hirai F, Okado Y, Sato Y, Tsurumi K, Ishikawa S, Beppu T, Koga A, Yoshizawa N, Higashi D and Futami K: Cancer risk in Japanese Crohn's disease patients: Investigation of the standardized incidence ratio. J Gastroenterol Hepatol 2013. | Article | PubMed

41. Raithel M, Weidenhiller M, Schwab D, Muller S and Hahn EG: [Pathobiology of dysplasia in chronic inflammatory bowel disease: Current recommendations for surveillance of dysplasia]. Z Gastroenterol 2001, 39:861-75. | Article | PubMed

42. De Backer Al, De Schepper AM and Pelckmans P: Polypoid and pseudopolypoid lesions of inflammatory bowel disease: diagnosis on double-contrast enema. Acta Gastroenterol Belg 1999, 62:190-5. Article I PubMed

43. Loddenkemper C: Diagnostic standards in the pathology of inflammatory bowel disease. Dig Dis 2009, 27:576-83. | Article | PubMed

44. Neumann H, Vieth M, Langner C, Neurath MF and Mudter J: Cancer risk in IBD: how to diagnose and how to manage DALM and ALM. World J Gastroenterol 2011, 17:3184-91. | Article | PubMed Abstract | PubMed Full Text

45. Chawla A, Judge TA and Lichtenstein GR: Evaluation of polypoid lesions in inflammatory bowel disease. Gastrointest Endosc Clin N Am 2002, 12:525-34, ix. | Article | PubMed

46. Odze RD: Adenomas and adenoma-like DALMs in chronic ulcerative colitis: a clinical, pathological, and molecular review. Am J Gastroenterol 1999, 94:1746-50. | Article | PubMed

47. Torres C, Antonioli D and Odze RD: Polypoid dysplasia and adenomas in inflammatory bowel disease: a clinical, pathologic, and follow-up study of 89 polyps from 59 patients. Am J Surg Pathol 1998, 22:275-84. | Article | PubMed

48. Toruner M, Harewood GC, Loftus EV, Jr., Sandborn WJ, Tremaine WJ, Faubion WA, Schroeder KW and Egan LJ: Endoscopic factors in the diagnosis of colorectal dysplasia in chronic inflammatory bowel 
Tanaka et al. Pathology Discovery 2013,

http://www.hoajonline.com/journals/pdf/2052-7896-1-1.pdf

disease. Inflamm Bowel Dis 2005, 11:428-34. | Article | PubMed

49. Warich-Eitel S, Katzenberger T and Eck M: [Polypoid dysplasia in inflammatory bowel disease: differential diagnosis and further diagnostic and therapeutic approaches]. Pathologe 2011, 32:282-8. | Article | PubMed

50. Goke R, Gregel C, Goke A, Arnold R, Schmidt H and Lankat-Buttgereit B: Programmed cell death protein 4 (PDCD4) acts as a tumor suppressor in neuroendocrine tumor cells. Ann N Y Acad Sci 2004, 1014:220-1. | Article | PubMed

51. Lankat-Buttgereit B and Goke R: Programmed cell death protein 4 (pdcd4): a novel target for antineoplastic therapy? Biol Cell 2003, 95:515-9. | Article | PubMed

52. Lankat-Buttgereit $B$ and Goke R: The tumour suppressor Pdcd4: recent advances in the elucidation of function and regulation. Biol Cell 2009, 101:309-17. | Article | PubMed

53. Asangani IA, Rasheed SA, Nikolova DA, Leupold JH, Colburn NH, Post $\mathrm{S}$ and Allgayer H: MicroRNA-21 (miR-21) post-transcriptionally downregulates tumor suppressor Pdcd4 and stimulates invasion, intravasation and metastasis in colorectal cancer. Oncogene 2008, 27:2128-36. | Article | PubMed

54. Fassan M, Pizzi M, Giacomelli L, Mescoli C, Ludwig K, Pucciarelli S and Rugge M: PDCD4 nuclear loss inversely correlates with miR-21 levels in colon carcinogenesis. Virchows Arch 2011, 458:413-9. | Article | PubMed

55. Ludwig K, Fassan M, Mescoli C, Pizzi M, Balistreri M, Albertoni L, Pucciarelli S, Scarpa M, Sturniolo GC, Angriman I and Rugge M: PDCD4/ miR-21 dysregulation in inflammatory bowel disease-associated carcinogenesis. Virchows Arch 2013, 462:57-63. | Article | PubMed

56. Zhang $Z$ and DuBois $R N$ : Detection of differentially expressed genes in human colon carcinoma cells treated with a selective COX-2 inhibitor. Oncogene 2001, 20:4450-6. | Article | PubMed

\section{Citation:}

Tanaka $T$ and Sugie S: Recent advances in pathobiology and histopathological diagnosis of inflammatory bowel disease. Pathology Discovery 2013, 1:1.

http://dx.doi.org/10.7243/2052-7896-1-1 